\title{
A EDUCAÇÃO BIBLIOTECÁRIA CATARINENSE: causas de seus pontos fracos, entre 1973 e 1993
}

\author{
Francisco das Chagas de Souza - chagas@ced.ufsc.br \\ Professor Adjunto Doutor \\ Departamento de Ciência da Informação \\ Universidade Federal de Santa Catarina
}

\begin{abstract}
Resumo:Relata os resultados de uma das etapas de pesquisa realizada no Departamento de Ciência da Informação da UFSC, cobrindo o período de 1973 a 1993, dentro da linha de investigação "Informação e Sociedade". O objetivo buscado é conhecer quais fatores contribuíram para que os dois cursos universitários de Biblioteconomia existentes em Santa Catarina tivessem fragilidades na relação entre suas atividades de ensino, pesquisa e extensão e a produção bibliográfica gerada pelos profissionais atuantes no Estado. Além de uma breve revisão de textos sobre as temáticas trabalho e educação, o artigo informa sobre os procedimentos adotados na pesquisa e, por fim, expõe algumas explicações encontradas para os pontos fracos.
\end{abstract}

Palavras-chave:

Biblioteconomia - Santa Catarina; Ensino de Biblioteconomia; Formação de bibliotecários.

\begin{abstract}
:
It tells the results of the one of the stages of research carried through in the Department of Information Science of the UFSC, covering period of 1973 - 1993, inside of the string of inquiry "Information and Society". The searched objective is to know which factors contributed so that the two existing university courses of Library Science in Santa Catarina State [Brazi] had fragilities in the relation enter its activities of education, research and services with the bibliographical production generated by the operating professionals in Santa Catarina State. Beyond one soon walk through texts on thematic the work and education, the article informs on the procedures adopted in this research and, finally, it displays some explanations found for the weak points.
\end{abstract}

Keywords:

Library Science - Santa Catarina; Education for Library professions.

\section{INTRODUÇÃO}

Já há algum tempo, desenvolve-se no Departamento de Ciência da Informação da UFSC uma pesquisa na linha de investigação Informação e Sociedade que vai além do livresco interpretativo e do técnico experimental. De outro lado, na medida em que avança rumo a uma consolidação, cada vez mais associa o levantamento, a interpretação da informação coletada por meio de informação de professores, ou de documentos utilizados para a ação de ensino, com a geração de infra-estrutura para a produção resultante de análise de informação, bem como realiza a produção de bases de dados. Esta infra-estrutura se constitui pelo NIPEEB Núcleo de Informação, Pesquisas e Estudos em Educação Bibliotecária e visa, em prazo mais imediato, produzir um conhecimento acerca da Educação Bibliotecária em Santa Catarina e, mais tarde, desta atividade na Região Sul do Brasil. Significativamente, através desta linha de investigação, os estudos em desenvolvimento indicam que é possível se dar a ênfase necessária à pesquisa educacional em Biblioteconomia que continua a ser um dos pontos mais fracos da atividade bibliotecária no Brasil. Este ponto fraco, tanto se revela em insuficiência teórica, dos diversos ângulos do estudo do conhecimento educacional, quanto na limitação metodológica dos processos e instrumentos de pesquisa aplicáveis no cruzamento das duas áreas.

A pesquisa de que resultou este artigo, se constitui em uma das etapas do projeto mais imediatamente relacionado à situação da educação bibliotecária em Santa Catarina. Na sua condução tem-se buscado uma visão 
mais ampla que a imediata relação escola / professor / aluno, partindo da idéia de que para além destes há um contexto que organiza uma cosmovisão ou um mundo de intervenção sobre e do sujeito. Por isso, tem-se tomado como fundamentação teórica a teoria sociológica do conhecimento, tendo como fonte principal Berger e Luckmann. Estes autores forjam a explicação de que a realidade que vivemos e na qual interagimos é construída socialmente, isto é, a partir do movimento humano nas relações primárias das estruturas familiais e secundárias das estruturas institucionais. Outra fonte teórica que se utiliza para a pesquisa é a Sociologia das Profissões. Nesta destaca-se como fonte principal Eliot Freidson. Destas referências teóricas, isto é, da Sociologia do Conhecimento e da Sociologia das Profissões, ambas produzidas a partir dos estudos dos autores mencionados no contexto norte-americano, parto para o conhecimento, através desta pesquisa, de como se dá a Educação Bibliotecária no Sul do Brasil e em Santa Catarina. Por contingências diversas, dentre as quais as relacionadas ao financiamento, venho explorando somente a realidade existente em Santa Catarina esperando, mais tarde, ter os meios materiais para alcançar toda a região sul do país. Assim, colocado sob a perspectiva sociológica do conhecimento, compreendo que profissões são papéis socialmente sancionados e, modernamente, são dependentes de profissionalização precedida de estudos universitários, na maioria dos ramos ocupacionais. Por esta razão, percebo que a ação da escola é múltipla e, em suas diversas variantes, precisa ser progressivamente estudada. De outro lado, aceito a perspectiva sociológica das profissões, de que as profissões fundadas, principalmente, na escolarização universitária necessitam constituir três pilares de sustentação e de dinamização os quais exigem uma atuação em linha com o movimento social. Eles são:

1. a existência de profissionais voltados às atividades técnico-executivas ou práticas, em contato com o usuário final dos serviços da categoria ou grupo profissional;

2. a existência de profissionais dotados de capacidade de organizar e de liderar politicamente a categoria ou grupo profissional; e

3. a existência de profissionais na categoria ou grupo profissional dedicados ao ensino e pesquisa social e aplicada para fundamentar ações profissionais e orientar os modos de conquista e ampliação de espaço social, com autoridade e competência.

Assim, por meio deste estudo, quero conhecer mais claramente como os profissionais dedicados à educação bibliotecária em Santa Catarina realizam práticas que efetivamente podem produzir a conquista e ampliação do espaço social profissional no estado. Ao mesmo tempo em que com esta pesquisa se tem esta intenção por meio dela também se pode cumpri-la pelo envolvimento com a investigação do tema, e, por extensão, também pelo envolvimento dos demais professores que oferecem dados sobre o seu trabalho cotidiano a serem utilizados como subsídios fundamentais à compreensão do problema. A ocorrência desta ação integrada produz um elo institucional profissional importante nesta missão que visa qualificar mais ainda o papel de bibliotecário sancionado por esta sociedade e fortalece o terceiro pilar profissional, supramencionado, o qual visa a sustentação e dinamização da profissão bibliotecária em Santa Catarina.

Com a realização do trabalho originador deste artigo se objetivou conhecer quais os fatores que contribuíram, de 1973 a 1993, para que os Cursos de bacharelado em Biblioteconomia de Santa Catarina [na UFSC e UDESC] apresentassem pontos fracos na sua ação didático-pedagógica. Dito de outro modo, desejavase conhecer que fatores, na organização de ambos os cursos, produziram, no desenrolar de suas atividades, uma 
precária articulação da escola com a produção bibliográfica gerada pelos profissionais da área atuantes no Estado.

Este objetivo foi elaborado após os resultados de um estudo anterior que mostrou a existência de pontos que representavam um estado de fragilidade nos cursos, especialmente quando se refere ao aproveitamento da produção bibliográfica específica gerada em Santa Catarina. Das conclusões então apresentadas naquele estudo, realizado de dezembro de 1997 a outubro de 1998, cuja análise está consubstanciada no relatório apresentado ao FUNPESQUISA em outubro de 1998, destacam-se os seguintes pontos fracos na atuação das duas escolas de Biblioteconomia que operam em Santa Catarina:

1. limitação de uso da produção bibliográfica local ou da produção do que interessar à formação de profissionais que sejam capazes de priorizar como mercado de trabalho o estado de Santa Catarina;

2. desconhecimento da produção estadual de Bibliografias, Guias e Tesauros.

3. alta concentração no uso didático de literatura produzida em eventos em apenas dois eventos profissionais realizados no país;

\section{ALARGAMENTO TEÓRICO DO TEMA}

No período coberto pela pesquisa, 1973 a 1993, a literatura produzida em Sociologia e Economia e a realidade material da sociedade revelam que o mundo e o Brasil vieram crescendo em transformações (desestruturação e desmonte do estado soviético, reunificação alemã, ressurgimento dos movimentos públicos favoráveis às idéias nazistas, fortalecimento dos estados islâmicos, reorganização do estado brasileiro com a retomada das eleições gerais e crescimento desmedido do número de municípios no país, fortalecimento de ONGs, privatização exagerada do ensino superior, desmonte do estado com a privatização de parte importante de empresas do estado ou de capital misto, crescimento do número de estabelecimentos escolares em todos os níveis, mudança do perfil dos setores econômicos, etc.) que se consolidaram já no início dos anos 90 e que não foram tematizadas claramente e inseridos como problemas pelos cursos de Biblioteconomia instalados no Brasil. Como se viu na pesquisa anterior, e consubstanciado no respectivo relatório, os Cursos instalados na UFSC e UDESC também passaram ao largo disso.

Uma das principais mudanças em nível internacional foi a profunda e rápida construção de uma infraestrutura científica e tecnológica a partir dos anos 70 que deu origem e fomento vigoroso ao que ora se chama de sociedade informacional ou sociedade da informação ${ }^{1}$. De fundo mais econômico, estas mudanças produzem, desde então, reformulações de impacto mundial nas relações de poder, na sociedade e na estrutura produtiva dos estados nacionais, assim como em segmentos sociais específicos, cuja análise detalhada tem sido feita por vários estudiosos, destacando-se entre eles Giddens, Castells, Harvey, Lojkine.

Naturalmente, todas estas mudanças refletem-se no mundo do trabalho e, por isso, igualmente no mundo das profissões, desembocando necessariamente no universo constituído pelo conjunto dos sistemas

\footnotetext{
${ }^{1}$ CASTELLS, M. em A era da informação... faz uma argumentação importante sugerindo que a designação mais apropriada para esta sociedade que vem se constituindo a partir do anos 1970 é "Sociedade informacional" embora seja dominante na área de Ciência da Informação a designação "Sociedade da Informação". Entretanto, tendo em vista os interesses desta pesquisa preferirei a designação "Sociedade informacional", especialmente por estar tratando do fenômeno educacional.
} 
educacionais, não como momento e fenômeno único, uniforme e verticalizado. Por esta razão, a discussão e reavaliação da atuação da escola em meio a estas mudanças, especialmente em nível de educação superior, é distinta, conforme a grandeza do impacto percebida em diferentes campos do conhecimento e em diferentes regiões geográficas e econômicas no mundo e no âmbito interno dos diversos países.

Sob esta perspectiva, é um fato concreto que a área de Biblioteconomia veio recebendo grandes impactos em sua atividade educacional durante os últimos vinte anos, tendo se verificado situações distintas. A primeira foi uma ampla reciclagem nos currículos ofertados nas escolas norte-americanas nos anos 80; a segunda foi a implantação de Cursos de Biblioteconomia em todo o território espanhol e a terceira foi o esforço na reestruturação da educação bibliotecária em países que já possuíam uma modelagem tradicional de educação bibliotecária vinculada a objetivos estatais com a França e a Suécia podendo ser tomadas como exemplos.

Todas estas mudanças vêm-se refletindo com escasso impacto sobre a Biblioteconomia brasileira, que somente a partir da metade da década de 90 passa a redefinir o perfil de sua infra-estrutura de educação bibliotecária, inicialmente com o reconhecimento de mudanças substantivas orientadoras da redenominação dos Departamentos de Ensino de Biblioteconomia. Com isso, podem assimilar sem choques com a regulamentação profissional de bibliotecário ${ }^{2}$ o caráter multidisciplinar do objeto de trabalho da Biblioteconomia, que cada vez mais exige equipes docentes com quadros oriundos de várias disciplinas acadêmicas.

De outro lado, para além dos aspectos de redefinição, expansão e infra-estrutura dessa educação, há questões relevantes acerca de desenho de currículo, procedimentos de planejamento, ensino e avaliação de aprendizagem que estão em discussão embrionária, envolvendo aí um esforço de aprofundamento, com alcance nos países do MERCOSUL, especialmente dirigidos a uma harmonização curricular entre os Cursos de Graduação instalados no Brasil, Argentina, Uruguai, Paraguai e Chile, desde 1996, através dos Encontros de Dirigentes das Escolas e dos docentes dos Cursos sediados nestes países.

Nesse trabalho de harmonização curricular, está embutida a idéia que orienta a sociedade informacional, nos termos na análise de Castells, que é a atuação em redes magnificando o processo em fluxo ${ }^{3}$.

Porém, ao longo desses quatro anos de discussão sob a perspectiva da harmonização curricular na região de influência do MERCOSUL não se enxerga um avanço efetivo da atuação em rede, no próprio Brasil, das Escolas de Biblioteconomia, seja na totalidade do país, na região sul e mesmo em Santa Catarina. Assim, problemas com relação aos processos de trabalho dos dois cursos instalados no estado tendem a persistir.

Tais circunstâncias podem estar refletindo a escassa discussão pelas equipes docentes destes Cursos de temas (como o ressurgimento dos movimentos públicos favoráveis às idéias nazistas no Brasil, reorganização política do estado brasileiro e crescimento desmedido do número de municípios no país, fortalecimento de ONGs, privatização exagerada do ensino superior, desmonte do estado com a privatização de parte importante de empresas do estado ou de capital misto, crescimento do número de estabelecimentos escolares em todos os níveis, mudança do perfil dos setores econômicos, etc) que não apenas repetem fenômenos mundiais como, no âmbito nacional e estadual, requerem a atenção dos cursos de ensino superior, sobretudo. Esses temas, tratados

2 A legislação profissional do Bibliotecário no Brasil é restritiva em relação a quem pode ser docente de Biblioteconomia. Com isso, existe uma ambigüidade sobre a pertinência dos Departamentos de ensino de Biblioteconomia poderem contar em seus quadros com pessoal que não tenha graduação em Biblioteconomia.

${ }^{3}$ No texto de CASTELLS, M. A era da informação ... esta idéia está colocada de modo bastante pertinente em relação ao atual estado econômico e político mundial, ao mesmo tempo em que há uma substantiva fundamentação para o significado da atuação em redes em escala mundial e seus impactos econômicos. 
como fenômenos mundiais ou nacionais, afetam imediatamente os conteúdos tratados em seus currículos, dado o próprio caráter ou jeito de ser da sociedade informacional. Esse horizonte temático se relaciona mais objetivamente com o pensar e agir sobre o mundo do trabalho, a educação, o processo escolar e a atuação docente na Sociedade Informacional e, em seu conjunto, contribui para a crise do modelo tradicional de currículo e permite a abertura do debate em torno de um novo ordenamento curricular.

Em relação ao mundo do trabalho é importante tomar-se inicialmente o entendimento do que o caracteriza. No início dos anos 80, no livro de André Gorz Adeus ao Proletariado, há uma síntese que evidencia com certa clareza o significado do termo e conceito trabalho. Diz ele: Atualmente [trabalho] designa uma atividade que se exerce: 1) por conta de um terceiro; 2) em troca de um salário; 3) segundo formas e horários fixados por aquele que paga; 4) visando fins que não são escolhidos por quem o executa. ... "Trabalho" hoje em dia designa praticamente apenas uma atividade assalariada. (p. 9)

Visto desta maneira, trabalho é nada mais que a venda do tempo de quem se assalaria a quem possa pagá-lo. É um meio de subsistência material do trabalhador que aceita contratual ou de modo tácito obedecer a uma disciplina na relação empregatícia. Mesmo assim, o trabalho não é um fato permanente pois convive com outros modos pelos quais os indivíduos podem adquirir meios de subexistência material. Desse modo, submetido ao modelo atual, o trabalho não é em si uma forma hegemônica e não existiu deste modo em todas as épocas. É por isso, fenômeno que apareceu em determinado momento do fluxo histórico do homem, constituindo elemento importante da sociedade capitalista, nos termos de Castells. Assim, é objeto de uma relação que existe amparada sob diversos modos de exercício e regulação.

Durante os anos 80 e 90, em que ocorreu a mais intensa informatização da sociedade em escala mundial, o caráter do trabalho se modificou. Sobre ele se evidenciaram as idéias e as práticas de flexibilização de contrato, de jornada e no corpo de trabalhadores aumentou substancialmente a inserção das mulheres como mãode-obra altamente qualificada mas desigualmente remunerada ou subempregada (Castells). Em outros termos, percebe-se a confirmação, como demonstrada por Castells, do que André Gorz, no livro já mencionado, afirmava em 1980: a abolição do trabalho é um processo em curso e que parece acelerar-se. (p. 11)

Porém, outra consideração que se deve fazer é que o trabalho, existindo com pleno emprego, ou com redução do emprego, constitui uma das mais fortes determinações educacionais, ou seja, uma das justificativas da existência dos sistemas educacionais é a preparação de futuros trabalhadores qualificados ou adaptados. Isto ocorre pelo fato de que o mundo do trabalho tradicionalmente requer disciplina do corpo trabalhador, domínio de conhecimentos ditos profissionais e capacidade de viver e de produzir transformações. À disciplina pode-se relacionar a acomodação contratual com produção ou horários, salários, condições locais de ambiente de trabalho, etc. Aos conhecimentos profissionais se associa o saber como fazer o que envolve o domínio dos processos de trabalho e da transformação da matéria-prima ou produção de serviço. À capacidade de viver e de produzir transformações se relaciona a administração pessoal da vida de trabalhador, incluindo aí o que incide sobre a disciplina e domínio de conhecimentos.

Pode-se afirmar, de outro lado, que nos últimos duzentos anos a educação, via escolarização, voltou-se para a forja dos alunos (a quase totalidade) para viverem uma vida adaptável ao mundo do trabalho (Perrenoud) ou seja, cada vez mais a escola volta-se à introjeção da disciplina, do conhecimento e do senso de transformação. Com isso, a escola com funções mais amplas, orientada à formação estético-humanista desinteressada ficou 
muito restrita, de maneira que quase todos os discursos educacionais terminam por vincular o conceito de educação escolarizada ao mundo do trabalho.

Nos discursos da década de 90, como em Castells, um analista da sociedade da Era da Informação, os conceitos de educação e conhecimentos especializados diferem entre si, embora ambos evoquem igualmente o trabalho. Ele diz: Deve-se estabelecer distinção entre o conceito de educação e de conhecimentos especializados. Conhecimentos especializados podem tornar-se obsoletos com rapidez mediante mudança tecnológica e organizacional. Educação ou instrução (diferentemente do internato de crianças e estudantes em instituições) é o processo pelo qual as pessoas, isto é, os trabalhadores, adquirem capacidade para uma redefinição constante das especialidades necessárias à determinada tarefa e para o acesso às fontes de aprendizagem dessas qualificações especializadas. Qualquer pessoa instruída, em ambiente organizacional adequado, poderá reprogramar-se para tarefas em contínua mudança no processo produtivo. (v. 3, p. 417)

Nessa mesma linha de compreensão e na mesma década, pode-se encontrar textos de educadores brasileiros. Um exemplo que confirma a associação da educação com o trabalho é o texto de revisão de Araci Catapan e Zeina Thomé Trabalho \& Consumo: para além dos parâmetros curriculares, o qual evoca o momento seguinte à sanção, no Brasil, mas que reflete um quadro mundial, de uma nova Lei de Diretrizes e Bases da Educação, em 1996, que rejeita um projeto discutido pela comunidade educacional do país por mais de cinco anos. Ao tratarem da relação educação e trabalho no capitalismo, as autoras dizem: Dado o desenvolvimento que as forças produtivas têm alcançado ainda no capitalismo, bem como a produção de riquezas culturais e materiais reveladoras do homem e apropriadas desigualmente; a existência de uma base técnica comum à produção e a intensidade de conteúdo técnico-científico inserido no processo produtivo, a cognição se apresenta como o presente e o futuro do trabalho, e a formação multidimensional como uma exigência universalizante e instrumento de luta nas sociedades tecnológicas. (p. 35)

Assim, parece evidente que o mundo do trabalho continua a definir o mundo da educação e, por contingência, determina também os estados de ensino e aprendizagem ou, em outros termos, o processo escolar. E, coerente com os sentidos de conhecer e transformar, próprios da educação voltada para uma qualificação de conteúdo cognitivo, isto é, direcionada à identificação e solução de problemas (Catapan e Thomé, p. 34) vai-se encontrar em Piaget (ver Lima) uma tipologia de memória que tem uma relação direta com o universo de atuação da escola. Por essa tipologia, resultante da observação do processo escolar, a escola realiza o seu trabalho enfatizando a aquisição do saber (memória) tanto pelo reflexo condicionado quanto pelo emocionalismo.

De acordo com o entendimento que retiro da exposição de Lima, a ação da escola se revela na introjeção dessas memórias nos indivíduos educandos. A primeira memória expressa-se pelo savoir-faire ou know-how ou habilidades como falar, andar, calcular, andar de bicicleta, tocar instrumento (... área pouca afetada pelas amnésias); a segunda memória expressa-se pela lembrança, que pode ser desfigurada com relação à realidade ... Os pesquisadores mostram que o melhor modo de evocar lembranças é através de uma reconstituição emocional ...(p. 219). Mas Lima chama a atenção para o fato de que o processo de ensino que enfatiza a primeira memória procede melhor do que aquele cuja ênfase dá à segunda. Em suas palavras $\mathrm{O}$ sistema escolar tradicional, sem se dar conta disso, apela para as emoções (medo, castigo, perda de status, etc.), como recurso de memorização ... o processo escolar todo é sustentado, em seu rendimento, pelas emoções geradas por prêmio e castigo (aprovação/reprovação) ... (p. 219). 
Visto deste modo, pode-se considerar que a escola tradicional serve mais ao mundo do trabalho na formação disciplinadora, pela via emocional, não oferecendo uma ênfase que sustente mais firmemente a formação para o conhecimento e transformação. Desse modo, pode ser uma escola pouco responsiva à carência de educação que Castells identifica no mundo da Era da Informação.

Do modo como compreendo, o processo escolar pode ser modelado pelo currículo e igualmente ser modelador do currículo, razão pela qual, no bojo da discussão deste tema, os teóricos chamam a atenção constante para a necessidade da superação do currículo tradicional e oferecem propostas de modalidades diferenciadas que poderiam responder mais adequadamente às mudanças mais recentes da sociedade.

Para chamar a atenção do perfil do currículo tradicional, Cunha analisa a obra de Tyler, Princípios básicos de currículo e ensino, tida como obra clássica neste tema, argumentando que nela o método precede o objeto. Em seu estudo, a autora afirma que Relacionando essa posição para o campo do currículo, poder-se-ia afirmar que todo aquele que busca o como planejar sem uma compreensão reflexiva e imanente do objeto estaria veiculando uma concepção tradicional do currículo. Ao longo de seu texto a autora, que utilizou a análise de conteúdo como técnica de investigação da obra de Tyler, consegue confirmar a postura positivista apresentada naquele texto, demonstrando no mesmo a ocorrência não apenas da precedência do método sobre o objeto (contexto de ação), mas demonstrando também que ao agir assim aquele texto ou seu autor faz desta concepção de currículo aquela que está consagrada como a tradição da construção curricular predominante que, entre outras coisas, nega a crítica e o fazer científico.

Até onde percebo, e pelo conjunto das discussões que venho produzindo em meus textos, esta fórmula Tyleriana, do currículo positivista, é de fato a mais utilizada na elaboração do currículo de Biblioteconomia que mesmo quando muda não parece tê-lo feito.

No período aqui estudado, vê-se que ocorreu pouca mudança na Educação bibliotecária brasileira, especialmente quando se compara a situação existente no período e as várias discussões e recomendações oferecidas desde 1978 quando do trabalho "O Ensino de biblioteconomia no Brasil" editado por Nice Figueiredo e realizado sob os auspícios da CAPES, até os inícios dos anos 90, passando pelos trabalhos de 1982, de Ana Polke: "O conteúdo curricular orienta a atuação do bibliotecário na linha predominantemente de execução de tarefas quando aprofunda a técnica e não leva em conta o ambiente contextual onde esta se aplica" (p. 77); de Lilia Vargas: "...temos consciência e falo porque acredito haver um consenso neste aspecto, por parte dos professores do Departamento de Biblioteconomia [UFRGS] de que o currículo precisa ser reestudado e isto de forma constante, pois novas exigências a cada dia se fazem ao profissional que ora formamos" (p. 79) e Evangelina Veiga: "Ao analisarmos o ensino da biblioteconomia no Brasil, não o podemos fazer de forma isolada. De nada vale a apreciação de programas, métodos e currículos que regem o nosso ensino, sem inseri-lo, antes, em um contexto maior" (p. 64).

Além das observações das autoras acima apontadas, o documento-síntese do Seminário de Otimização do Ensino de Biblioteconomia, realizado em novembro de 1982, em Recife, PE, (no mês seguinte à deliberação (em 29/10/82) que estabeleceu a Resolução CFE 08/82, a qual configurou o novo Currículo Mínimo de Biblioteconomia), apontava como "dificuldades e sugestões para implantação do novo Currículo" as seguintes:

1. Nem todos os cursos estão ligados a Universidades Federais o que dificulta, de certa forma, a integração de docentes de outras áreas que ministram os conteúdos das matérias de Fundamentação Geral e Instrumentais, voltadas para os objetivos da biblioteconomia; 
2. Impossibilidade de contratar pessoal docente;

3. Desatualização dos docentes em relação ao novo currículo;

4. Recursos locais para a reciclagem de docentes são impossíveis;

5. As reciclagens deveriam ser por áreas de estudos e regionais;

6. A ABEBD orientar também os Programas;

7. Fazer reuniões de docentes por matérias;

8. Os Seminários pedagógicos devem continuar;

9. Os docentes precisam de maiores conhecimentos sobre as técnicas de ensino. É necessário continuar oferecendo oportunidades aos professores de reflexão sobre a forma como estão se conduzindo na sala de aula;

10. O novo currículo deverá influenciar o comportamento do professor e do aluno. Será preciso mudar também a forma do ensino, tornando o aluno participante do seu processo de aprendizagem.

Deve-se ressaltar que essas recomendações e sugestões tinham alcance nacional. Mais tarde, em 1993, um exemplo da recorrência e das dificuldades persistentes no ensino de Biblioteconomia pode ser visto nas recomendações do III encontro de Escolas de Biblioteconomia da Região Sul, realizado em Florianópolis, de 11 a 12 de novembro. A terceira recomendação desse Encontro dizia respeito especificamente ao ensino de Biblioteconomia, prevendo as ações seguintes: de curto prazo: definir procedimentos didáticos e de avaliação; de médio prazo: curso de complementação pedagógica; de longo prazo: analisar como uma área de concentração: metodologia de ensino.

Vista como conjunto, estas diversas manifestações acima elencadas expõem de modo substantivo, através do reconhecimento nacional e local, a dificuldade do docente de biblioteconomia em ver-se preparado para o exercício do ensino, ao longo de todo um período de quinze anos, no qual, no mínimo, cada escola formou quinze turmas. Assim, quando falam em currículo a ser atualizado e em metodologia e técnicas de ensino a empregar, esses discursos expõem a distância que existe entre o conhecimento técnico-profissional bibliotecário e o conhecimento didático-pedagógico daqueles que passaram a ser professores, evocando assim uma real dificuldade de linguagem mais apropriada para a atividade de ensino.

Esta situação não se revela apenas no ensino superior profissional brasileiro. Ela constitui discussão permanente em âmbito internacional, em todos os níveis educacionais, tanto na teoria como na prática. Nesse sentido, é importante a discussão encetada por Horst Rumpf em seu texto Los conocimientos no se pueden trasmitir a otros como informaciones. Também é interessante a abordagem que carrega o texto Por uma teoria da Pedagogia: pesquisas contemporâneas sobre o saber docente em que Clermont Gauthier e outros sistematizam um grande elenco de pesquisas realizadas nas salas de aula nas últimas décadas. Neste texto, os autores têm como objetivo contribuir com uma visão mais ampla dos saberes profissionais próprios dos professores e, compreender a ação pedagógica do professor, isto é, estudar "o que o mestre faz para instruir e educar os alunos" (p. 173). Naturalmente, o objeto de C. Gauthier e outros está mais relacionado ao professor do que no Brasil corresponde ao ensino fundamental e médio e, geograficamente, abrange os professores atuantes na América do Norte (Estados Unidos e Canadá). No seu livro, são apresentadas duas funções básicas do professor que se tornam relevantes para esta discussão: O professor exerce duas funções básicas que denominamos de "gestão do conteúdo" e de "gestão da classe". (p. 175). Contudo, ao final da pesquisa, eles concluem que o saber docente 
não é confinado por certezas. Para decidir, ele [professor] se serve do seu reservatório de saberes. Nele [professor] estão armazenados vários saberes nos quais ele pode se apoiar: saberes disciplinares, saberes experienciais, saberes curriculares, saberes da tradição, etc ... Saberes da ação pedagógica ... (p. 400).

Esses saberes diversos, pelo que entendo, tendem a produzir leituras diversas da realidade o que leva, em qualquer época, ao conflito de expectativa do docente e do estudante sobre qual o modelo mais apropriado para a educação e formação de recursos humanos ou de homens cidadãos.

Colocando em perspectiva um aluno participante ou envolvido mais intensivamente com o processo de aprendizagem, Jurjo Santomé faz a defesa do que chama de currículo integrado enfatizando que toda a proposta de currículo integrado parte de que cada estudante tem o seu próprio ritmo de desenvolvimento, estratégias peculiares de aprendizagem, experiências pessoais idiossincráticas, diferentes expectativas, distintas informações prévias, etc. ... Por essa razão [diz] é preciso propor ao conjunto de estudantes de cada aula a possibilidade real de numerosas tarefas escolares diferentes, sobre a base de meios didáticos também variados, em que possam entrar em acção, interesses e motivações próprias de cada estudante em particular, para por em prática uma autêntica personalização da aprendizagem. Em todo o seu estudo, abundam as caracterizações da escola tradicional como estruturada ou produtora de fragmentação, artificialismo, distanciamento do contexto dos alunos, etc. que em tudo parece inadequada ao discurso que deseja expressar o perfil do mundo dos anos finais da década de oitenta e início de noventa. Aliás, ao final de seu estudo, Jurjo Santomé, chama a atenção para o fato de que o currículo integrado É uma maneira de aprender a movimentar-se em estruturas flexíveis, numa sociedade e momento histórico onde também a palavra flexibilidade se converteu numa das palavras mágicas ...

Frente às várias possibilidades de organização curricular e de conduta profissional como docente, às limitações contextuais para a sua atuação e à incerteza do próprio professor de biblioteconomia brasileiro quanto ao seu preparo para o ensino, como eram e como estavam os professores de Biblioteconomia da UFSC e da UDESC no período pesquisado, ou melhor, como estavam estas escolas, em relação aos seus quadros docentes, que terminavam produzindo uma precária articulação da escola com a produção bibliográfica gerada pelos profissionais da área atuantes no estado?

\section{PONTOS FRACOS IDENTIFICADOS: investigando as suas causas}

No relatório da pesquisa precedente, se concluiu que os pontos fracos então identificados na atuação das escolas catarinenses de Biblioteconomia demonstravam que no período coberto:

a) as escolas não conheciam os interesses locais em torno do que devia ser dado como objeto de pesquisa;

b) faltava-lhes uma visão mais clara sobre que textos e tipos de textos deve produzir;

c) agiam como reprodutoras, sobretudo, das idéias concebidas no eixo Rio de Janeiro - São Paulo Brasília.

Concluía-se também que estes aspectos mostravam a insustentabilidade da não reciclagem das escolas de biblioteconomia sediadas em Santa Catarina em termos de pensamento e ação, pois como parte da instituição bibliotecária catarinense não contribuía para a formação de um pensamento aplicado ao contexto local e nem 
produzia teoria e nem outros segmentos bibliotecários catarinenses também o faziam, na medida em que teoricamente, conforme a Sociologia das Profissões é o grupo acadêmico que detém este papel como principal. Assim, perguntava-se no respectivo relatório "se os intelectuais da profissão em Santa Catarina não expressam um pensamento bom e útil para o uso didático na formação de profissionais no estado, quem o faz?"

Para buscar as causas que contribuíram para a produção dos pontos fracos identificados partiu-se com a seguinte estratégia:

1. Identificação dos professores da área de Biblioteconomia, atuantes nos cursos de Biblioteconomia da UFSC e da UDESC, de 1973 a 1993, e coleta de informações junto aos mesmos a partir do uso de um instrumento de coleta de dados apropriado;

2. Análise e interpretação das informações fornecidas tendo como parâmetro a literatura educacional e sociológica pertinente

Com a adoção desta estratégia foi possível desenvolver as seguintes operações:

\section{a) Identificação dos Docentes}

Foram identificados um total de 31 docentes entre ativos e aposentados, sendo 11 na UDESC conforme listagem fornecida pela secretária da FAED - Faculdade de Educação - à qual está vinculado o Curso e 20 na UFSC conforme listagem fornecida pelo Departamento de Ciência da Informação.

\section{b) Elaboração e Aplicação de Instrumento de Coleta de Dados}

$\mathrm{Na}$ condição de pré-teste do instrumento de coleta, um questionário foi inicialmente aplicado como piloto para dois docentes da UFSC e um aposentado da UDESC que na época atuava com contrato temporário na UFSC. Após esta aplicação foram realizadas alterações no instrumento a fim de melhor adequá-lo aos docentes.

\section{c) Aplicação do questionário}

O questionário definitivo foi enviado a 26 docentes, sendo, dez da UDESC e dezesseis da UFSC. Antes do envio postal dos questionários realizou-se contato por telefone com 15 docentes a fim de consultar e verificar a possibilidade de responderem ao mesmo. Foram enviados, por correio, 15 questionários para professores aposentados, afastados ou em licença e, em mãos, foram entregues 11 questionários, para o pessoal ativo, principalmente os docentes da UFSC já que na época de aplicação dos questionários a UDESC estava em período de férias. Dos 15 questionários enviados pelo correio retornaram 6 e dos entregues em mãos retornaram 10 respondidos. No total, dos 26 questionários enviados, 1 retornou, sem resposta, por incompatibilidade de endereço, 1 não foi analisado por não se enquadrar no período pesquisado restando 14 respondidos em condições de análise, dos quais 5 de professores da UDESC e 9 de professores da UFSC.

\section{d) Tabulação dos Dados}

A tabulação dos dados foi realizada em três etapas visando facilitar o processo de análise. Na primeira seguiu-se o roteiro de questões estabelecido no instrumento de pesquisa; na segunda seguiu-se um roteiro de análise individualizada a partir do cruzamento de questões comuns; na terceira seguiu-se um roteiro individualizado de eixos de análise. 


\section{e) Interpretação dos resultados}

\section{OS CURSOS DE BIBLIOTECONOMIA EM SANTA CATARINA: criação e cotidiano de trabalho entre 1973 e 1993}

Os Cursos de Biblioteconomia surgiram em Santa Catarina no mesmo ano. Segundo documentos oficiais, o Curso de Biblioteconomia da UDESC foi aprovado pelo parecer 453/73 e implantado em 1974, tendo obtido reconhecimento pelo Decreto Federal 81502, de 30/03/78. Em sua história consta que de 1980 a 1983 não realizou concurso vestibular, sendo reativado em 1984, com a oferta de vagas para o município de Blumenau. O Curso de Biblioteconomia da UFSC foi implantado em 1973, recebendo reconhecimento do CFE em 08/11/77 pelo Parecer 3.129, confirmado pelo Decreto Federal 81.144 de 02/01/78.

Inicialmente, formaram seus quadros docentes com professores contratados provisoriamente, alguns vindos de outros estados e atuando simultaneamente nos dois cursos. Em 1987, dados do então Departamento de Biblioteconomia e Documentação da UFSC indicavam um quadro total de 19 professores, sendo 12 Mestres e 7 especialistas. Em novembro de 1993, em levantamento feito por ocasião do III Encontro das Escolas de Biblioteconomia da Região Sul, as duas escolas tinham a seguinte situação:

TABELA 1

\begin{tabular}{|l|l|l|}
\hline SITUAÇÃO & UFSC & UDESC \\
\hline Número de professores & 18 & 13 \\
\hline Regime de trabalho & & \\
- dedicação exclusiva - DE & 16 & 5 \\
\hline Titulação & & \\
- doutor & 2 & 1 \\
- mestre & 8 & 3 \\
- especialista & 7 & 7 \\
- bacharel & 1 & 2 \\
\hline
\end{tabular}

Dados obtidos para esta pesquisa, com a contribuição da bolsista Francisca Rasche, informam sobre vários outros itens aqui reunidos como subsídios para uma análise mais ampla. Estes dados tratam de:

- vinculo de trabalho ou vínculo institucional do docente

- formação pessoal e acadêmica

- $\quad$ atualização permanente na área

- experiência profissional anterior à atuação no ensino

- formação acadêmica para o ensino

- $\quad$ atividades de ensino na graduação

- $\quad$ atividades de extensão

- $\quad$ atividades de pesquisa

- envolvimento no planejamento de ensino

- $\quad$ auto-avaliação quanto ao valor da pesquisa que produzia 
Estes dados mostram a situação das duas escolas no período estudado, a partir das informações fornecidas pelos/as docentes em resposta ao questionário que lhes foi remetido ou entregue diretamente.

Quanto ao item vinculo de trabalho ou vínculo institucional do docente foi verificado: a) ano de contratação ou de ingresso no Curso e b) regime de trabalho que lhe foi atribuído no período. Para o indicador "ano de contratação" se obteve informações mais detalhadas da UFSC, conforme a tabela abaixo:

TABELA 2

\begin{tabular}{|l|l|}
\hline ANO DE CONTRATAÇÃO / UFSC & Número de docentes \\
\hline 1976 & 7 \\
\hline 1978 & 3 \\
\hline 1979 & 1 \\
\hline 1980 & 1 \\
\hline 1983 & 1 \\
\hline 1985 & 1 \\
\hline 1988 & 1 \\
\hline 1989 & 1 \\
\hline 1990 & 1 \\
\hline 1991 & 2 \\
\hline 1993 & 1 \\
\hline TOTAL & $20^{*}$ \\
\hline
\end{tabular}

* Neste total há a sobreposição de números em face de aposentadorias

e / ou transferências de docentes a seguir substituídos

Com relação à UDESC os dados são parciais e captados a partir dos 5 questionários que foram devolvidos em resposta à pesquisa e são os seguintes:

TABELA 3

\begin{tabular}{|l|l|}
\hline ANO DE CONTRATAÇÃO / UDESC & Número de docentes \\
\hline 1976 & 2 \\
\hline 1979 & 1 \\
\hline 1988 & 1 \\
\hline sem informação & 1 \\
\hline
\end{tabular}

Em relação ao indicador "regime de trabalho" só foi possível analisar com segurança as informações fornecidas pelos questionários que retornaram. Assim, obteve-se os seguintes dados:

TABELA 4

\begin{tabular}{|l|l|l|}
\hline REGIME DE TRABALHO* & UDESC & UFSC \\
\hline Dedicação Exclusiva - DE & 3 & 8 \\
\hline 40 horas & 1 & - \\
\hline 20 horas & 1 & 1 \\
\hline
\end{tabular}

* 1 informante manteve contrato de trabalho de 20 horas, entre 1973 e 1988, com ambas as escolas, passando em 1989 a atuar apenas na UFSC com contrato em regime de DE.

Quanto a Formação Pessoal e Acadêmica foram considerados os dados relativos à: 1) titulação e área de formação no nível de graduação e 2) domínio de idiomas estrangeiros pelos docentes. Utilizando-se os dados captados nos questionários, vê-se na tabela abaixo os dados referentes ao indicador 1:

TABELA 5

\begin{tabular}{|l|l|l|l|l|}
\hline Titulação mais alta & Curso de formação na graduação & UDESC & UFSC & TOTAL \\
\hline
\end{tabular}




\begin{tabular}{|l|l|l|l|l|}
\hline Doutor & Direito & 0 & 1 & 1 \\
\hline Mestre & Biblioteconomia & 3 & 5 & 8 \\
\hline Especialista & Biblioteconomia & 2 & 2 & 4 \\
\hline Graduado & Biblioteconomia & 0 & 1 & 1 \\
\hline
\end{tabular}

No indicador "domínio de idiomas estrangeiros", o espanhol teve 11 indicações do total de informantes, seguido do inglês com 10 indicações, do francês com 4 indicações, do italiano e alemão com uma indicação cada. Dois docentes não responderam a essa questão e somente três indicaram o domínio de apenas um idioma estrangeiro.

Quanto à Atualização Permanente buscou-se respostas a respeito do percentual de conhecimento da literatura catarinense da área de Biblioteconomia, Arquivologia, Ciência da Informação e Documentação. Esta questão não foi respondida por cinco docentes. Dos que responderam, três disseram conhecer até $20 \%$ da literatura bibliotecária catarinense e outros três indicaram conhecer entre 50 e $75 \%$. Dois respondentes indicaram conhecer entre 75 e $100 \%$ e um indicou conhecer entre 20 e 50\%. Isto significa que 5 docentes indicaram conhecer $50 \%$ ou mais da literatura produzida em Santa Catarina.

Sobre o nível de conhecimento da literatura estrangeira, uma limitação vinha do fato de que em torno de metade dos respondentes disseram dominar medianamente os idiomas indicados quando perguntados a respeito dos idiomas conhecidos. Três disseram conhecer bastante idiomas e 2 indiciaram dominar só um pouco. Duas pessoas não responderam a essa questão.

Em relação ao item Experiência Profissional Anterior à Atuação no Ensino foram identificados os tipos de instituições em que os docentes atuaram e o tempo de atuação. Sobre os tipos de instituições indicadas aparecem com destaque a biblioteca especializada e a biblioteca universitária, com 5 docentes, seguida da biblioteca pública com 4 docentes e centro de documentação com 2 docentes. Três docentes disseram não ter atuado anteriormente na área.

Quanto ao tempo de experiência anterior ao ingresso no ensino, se destaca a indicação de tempo zero para 4 docentes.

Dois docentes, indicaram um tempo de 6 anos de experiência profissional anterior ao ensino. Nas outras indicações, 1 docente cada, ocorrem variações que vão desde um tempo de um semestre até 23 anos. Apenas um docente não respondeu esta questão.

No item Formação Acadêmica para o Ensino Superior buscou-se respostas com relação à preparação do respondente em termos de ter cursado disciplinas como metodologia do ensino superior ou didática do ensino superior antes de ingressar no ensino. Das respostas obtidas têm-se que 4 docentes cursaram uma das disciplinas em questão antes de ingressar no ensino; 6 docentes, disseram ter cursado após o ingresso no ensino; 3 docentes disseram não ter cursado a disciplina em nenhum momento; 1 docente não respondeu a questão.

Acerca das Atividades de Ensino na Graduação obteve-se que dentre as disciplinas ministradas na graduação pelos docentes pesquisados se destacam: arquivística; bibliografia especializada; classificação; controle bibliográfico; estágio supervisionado; indexação; metodologia científica; normalização da documentação. De modo geral, há destaque para disciplinas que tratam do controle e tratamento da informação.

No item Atividades de Extensão dos questionários respondidos, têm-se que 8 docentes afirmam não acumular função de ensino com outra atividade e 1 não respondeu. Dos que responderam é possível listar as seguintes funções: direção da Biblioteca Universitária -UFSC; responsabilidade pelo setor de processos técnicos do sistema da Biblioteca Pública do Estado de Santa Catarina, da Biblioteca Universitária -UDESC e da ACAFE 
(Associação Catarinense das Fundações Educacionais); chefia de departamento de ensino; bibliotecário de referência; coordenação de atividade de documentação da Secretaria de Administração do estado.

Vê-se, pela lista, que as atividades desenvolvidas pelos docentes em paralelo com o ensino apresentam caráter administrativo e técnico.

Em Atividades de Pesquisa dos questionários analisados 12 dos docentes disseram ter publicado ou apresentado trabalhos no período em questão, outros 2 disseram não ter publicado trabalhos no período. Destacase que dentre os que responderam que publicaram/apresentaram trabalhos, uma pessoa mencionou não priorizar tal prática em seu dia-a-dia profissional.

Em relação ao Planejamento do Ensino os docentes foram questionados a respeito: a) da adoção de literatura estrangeira e b) de indicação de textos de autoria própria. Dez docentes responderam afirmativamente que indicaram literatura estrangeira, 3 disseram não ter indicado tal literatura e 1 não respondeu.

Das razões apontadas para a indicação de literatura estrangeira foi explicitado que: $80 \%$ da literatura mundial está em inglês; não existe literatura adequada em português; era a única literatura disponível; tratava-se de literatura fundamental na ministração das disciplinas; era literatura adequada ao aprimoramento do conhecimento. Dos que responderam não indicar a literatura estrangeira têm-se: o caráter prático da maioria dos programas; literatura nacional suficiente; não domínio de outros idiomas pelos alunos.

Quanto ao indicador "adoção de textos de autoria própria", encontrou-se que 9 docentes adotaram textos próprios, 3 que não responderam e 2 que disseram não, embora tenha-se constatado que produziram textos no período.

A título do docente fazer uma Auto-Avaliação da Pesquisa que Produziu perguntou-se sobre a utilização de seus textos por outros docentes. Nove consideraram ser possível o uso de seus textos por outros docentes apontando razões como:

- pode constituir referencial teórico

- não tem caráter estritamente técnico - pois trata de conteúdos abrangentes;

- trata-se de exercício para a realização de prática;

- é útil para disciplinas práticas.

Duas pessoas indicaram resposta negativa, sendo que uma delas justificou que seus textos não são didáticos.

Além da captação desses dados que forneceram mais claramente uma caracterização dos respondentes, buscou-se também aspectos relacionados à sua atuação didático-pedagógica. Para isso, formularam-se questões sobre:

- Elaboração de programas de ensino

- Conhecimento da existência de critérios oficiais na instituição onde atuavam para fins de orientar a adoção de bibliografia

- Os critérios que adotou na seleção ou citação da bibliografia

Para o item Elaboração de Programas de Ensino verificou-se nas respostas que 10 dos respondentes apontaram para a existência de roteiro oficial aprovado pela universidade onde atuavam para a elaboração de programas de ensino. Dois indicaram a não existência de tal roteiro e dois não responderam a questão. 
Acerca do item Critérios em Roteiro Oficial para a Adoção de Bibliografias dos que indicaram existir tais critérios têm-se duas indicações cada para o critério atualidade, disponibilidade e outro fator e uma indicação cada para autoridade e idioma em que dividem-se as preferências na seguinte ordem: $1^{\circ}$ português, $2^{\circ}$ espanhol e $3^{\circ}$ inglês.

Quanto ao item Critérios Adotados na Seleção da Bibliografia 10 docentes afirmaram que é utilizada a seguinte ordem de preferência: $1^{\circ}$ - atualidade; $2^{\circ}$ autoridade; $3^{\circ}$ disponibilidade; $4^{\circ}$ idioma $\left(1^{\circ}\right.$ português, $2^{\circ}$ inglês, $3^{\circ}$ espanhol, $4^{\circ}$ francês, $5^{\circ}$ outros); $5^{\circ}$ preferência pessoal; $6^{\circ}$ outro fator.

\section{CAUSAS DOS PONTOS FRACOS E SUA ANÁLISE E INTERPRETAÇÃO}

Os pontos fracos identificados na pesquisa anterior e aqui referidos podem levar imediatamente a duas atitudes: a) a negação de sua ocorrência e b) o estudo das causas de sua ocorrência. Em virtude da necessidade profissional de fortalecimento da categoria, a fim de que esta possa responder aos novos desafios apresentados pela realidade em mutação permanente nos âmbitos tanto das instituiçòes quanto das famílias, negar a ocorrência daqueles pontos fracos na educação bibliotecária catarinense, no período em perspectiva, não contribuiria positivamente para a avaliação do que foi realizado não auxiliando, por conseguinte, os programas de reciclagem, atualização e educação contínua. Com isso, o mais coerente é trabalhar no sentido de responder a segunda atitude, isto é, realizar um esforço voltado para a identificação dos pontos fracos, analisar seus traços característicos e interpretá-los como fenômeno da trajetória dos Cursos ou Escolas em apreciação, instalados na UFSC e UDESC, como espaço de institucionalização da formação universitária para o exercício da profissão bibliotecária em Santa Catarina.

No entanto, pontos fracos não são um absoluto em si, mas se revelam somente quando comparados a indicadores que os refletem como dotados de algum grau de negatividade.

Com a finalidade de construir aproximações que possam repesentar um conjunto de indicadores de contraste, busquei na literatura de caráter social e ou educacional correspondente ao período da pesquisa idéias que permitissem uma síntese que pudesse me levar ao alcance da meta proposta. A síntese até aqui elaborada contém as seguintes idéias:

\section{QUADRO 1}

\begin{tabular}{|c|c|}
\hline Período & Idéias \\
\hline Anos 70 & $\begin{array}{l}\text { - A partir desses anos passa a se constituir em âmbito mundial a sociedade informacional, com } \\
\text { uma infra-estrutura econômica estabelecida como matriz de uma nova configuração para a } \\
\text { condução do estado e a produção de bens e serviços; } \\
\text { - A partir desses anos o mundo do trabalho passa a se transformar em um espaço de contínua } \\
\text { modificação das relações de emprego; } \\
\text { - A partir do final desses anos, no Brasil, há um claro reconhecimento por docentes e } \\
\text { pesquisadores de Biblioteconomia, de que o currículo desta área, como praticado, distancia o } \\
\text { aluno da visão do contexto ambiental brasileiro, quadro que se agrava pela desatualização dos } \\
\text { docentes, ausência de meios locais para a sua reciclagem, carência do domínio das técnicas de } \\
\text { ensino, necessidades de realização de seminários pedagógicos, necessidade de mudar a forma de } \\
\text { ensino, inclusive permitindo-se maior participação no processo de sua formação }\end{array}$ \\
\hline Anos 80 & $\begin{array}{l}\text { - A partir desses anos ocorre a expansão, em âmbito internacional, da Biblioteconomia como } \\
\text { profissão e campo de trabalho; } \\
\text { - A partir do final desses anos, há a apropriação progressiva da operação em rede tanto nas }\end{array}$ \\
\hline
\end{tabular}




\begin{tabular}{|l|l|}
\hline & $\begin{array}{l}\text { empesas como um todo, quanto nos governos e universidades. Nesse sentido, um fenômeno que } \\
\text { vem crescendo são os consórcios de universidades e de bibliotecas universitárias; } \\
\text { - A partir do final desses anos, debate-se em âmbito internacional, que o ensino deve ser } \\
\text { transformado de modo a que o conhecimento não seja meramente transmitido de maneira } \\
\text { informativa }\end{array}$ \\
\hline Anos 90 & $\begin{array}{l}\text { - Nesses anos, se estabelece uma clara distinção entre educação e conhecimentos } \\
\text { especializados, acreditando-se que o segundo está aberto à rápida obsolescência em face dos } \\
\text { avanços tecnológicos que os meios de produção vêm sofrendo; } \\
\text { - A partir desses anos, cada vez mais se aceita que é necessário uma educação } \\
\text { multidimensional, com currículos mais integrados e flexíveis, direcionados ao ensino por } \\
\text { projetos, com ênfase na formação pelo reforço da memória do saber porque fazer; } \\
\text { - Nesses anos, se discute mais claramente a necessidade da superação do sistema escolar } \\
\text { tradicional, com o abandono do currículo positivista; } \\
\text { - Nesses anos, em âmbito mundial, passa-se a perceber o trabalho do professor como } \\
\text { dependente de vários saberes, todos igualmente fundamentais para o seu trabalho: saberes } \\
\text { disciplinares, saberes experienciais, saberes curriculares, saberes da tradição, saberes da ação } \\
\text { pedagógica, etc. }\end{array}$ \\
\hline
\end{tabular}

Ao tomar esta síntese, que certamente não é em si completa, tentarei fazer o seu confronto com o que se captou em relação à escola de Biblioteconomia em Santa Catarina. A partir disso, pretendo gerar uma explicação para os pontos fracos dessa escola, ou melhor, identificar por quais razões existiram estes pontos fracos.

Das respostas obtidas junto aos Cursos e das fornecidas pelos professores, referentes ao período de 1973 a 1993, pode-se fazer a seguinte síntese:

- 31 professores trabalharam no ensino superior de Biblioteconomia em Santa Catarina no período;

- 21 desses professores tinham regime de trabalho em dedicação exclusiva, supondo-se que além do ensino realizavam pesquisa e extensão ao ele integradas;

- Dos 31 professores, apenas 3 completaram a formação em nível de Doutorado;

- Encontrou-se apenas 1 professor que não tinha bacharelado em Biblioteconomia;

- Não é quantitativamente representativo o conhecimento que tinham da literatura especializada produzida em Santa Catarina;

- A língua estrangeira conhecida por um número maior desses docentes era o espanhol;

- Metade dos docentes que prestaram informações não tinham experiência de trabalho ou na Biblioteconomia ou em atividades que envolvessem conhecimentos universitários;

- Menos de 1/3 daqueles que responderam a pesquisa tinham cursado uma disciplina de Metodologia ou Didática de Ensino Superior antes do ingresso na atividade docente;

- As atividades de extensão que exerciam tinham caráter de deslocamento técnico ou administrativo.

Retomando os pontos fracos identificados, verificou-se que os docentes:

- usavam de modo limitado a produção bibliográfica local ou a produção necessária à formação de profissionais capazes de priorizar como mercado de trabalho o estado de Santa Catarina;

- desconheciam a produção estadual de Bibliografias, Guias e Tesauros.

- utilizavam didaticamente, de modo predominante, a literatura "cinzenta" produzida em apenas dois eventos profissionais realizados no país.

Uma hipótese de explicação que cheguei a formular no relatório da pesquisa anterior foi o de que os pontos fracos eram provocados pelo fato de que:

Enc. Bibli: R. Eletr. Bibliotecon. Ci. Inf., ISSN 1518-2924, Florianópolis, Brasil, n.9, p.29-53, 2000. 
a) as escolas não conheciam os interesses locais em torno do que devia ser dado como objeto de pesquisa em biblioteconomia;

b) as escolas não tinham uma visão mais clara sobre que textos e tipos de textos seus professores deveriam produzir;

c) as escolas funcionavam como espaço de reprodução das idéias biblioteconômicas que circulavam no eixo Rio de Janeiro - São Paulo - Brasília.

Por parcial e incompleta, esta hipótese continua aberta à exploração e espero que nesta etapa de trabalho seja possível ampliar a explicação até então construída.

A síntese acima enunciada a partir das informações captadas junto aos Cursos e aos Professores permitem compreender o alcance de certos traços causais da fraqueza da escola catarinense de Biblioteconomia entre 1973 e 1993. Por isso, a partir daqui iniciarei uma apreciação mais detalhada do que ali foi apresentado.

Uma evidência exposta pelos dados é que o contingente docente na área de Biblioteconomia no Estado, em relação do total de membros do grupo profissional atuante não era pequeno e representava, no período, em torno de dez por cento dos profissionais habilitados. Além disso, setenta por cento do total de docentes era contratado em regime de Dedicação Exclusiva, o que favoreceria o envolvimento mais consistente com a pesquisa e a extensão.

A grande limitação, de fato verificável, estava precisamente na inexistência de quadros para a execução de atividades de pesquisa. Se for considerado o fato de a área biblioteconômica ser exaustivamente prática e de que a atividade de pesquisa requer uma certa densidade teórica, e também considerado que os três doutores identificados titularam-se no final dos anos oitenta e início dos noventa, então havia insuficiência de quantidade de pessoal e de tradição de pesquisas nas escolas de Biblioteconomia da Santa Catarina. Alie-se a isso, o fato de que nessas escolas não havia o espaço acadêmico para o discurso e a prática da descoberta e da crítica do conhecimento. Algumas razões levavam a isso: 1 - os quadros docentes dos Departamentos de Ensino de Biblioteconomia eram constituídos, quase integralmente, por bibliotecários formados sob a ditadura da técnica; 2 - existe - historicamente - acentuada ausência de fundamentação teórico-social na formação acadêmica do bibliotecário brasileiro e esses docentes, em geral, mantém essa lacuna.

Também é em face disso que se explica o fenômeno da maioria do professorado investigado não conhecer a produção bibliográfica local e mesmo as fontes secundárias aqui produzidas no período em estudo. Do mesmo modo que faltava a acuidade para o conhecimento da literatura local, faltavam as condições para enxergar mais amplamente a literatura internacional decorrente da limitação de alcance linguistico, o que provocava a redução do acesso à literatura estrangeira. Por uma e outra dessas situações também não se tornavam evidentes as preocupações com a contemporaneidade da Sociedade Informacional e com as modificações que estavam acontecendo no mundo do trabalho no período. O discurso da escola de Biblioteconomia em Santa Catarina ainda estava centrado, de um lado, nas técnicas biblioteconômicas de sempre, submetido à linearidade e verticalidade dos códigos de descrição bibliográfica e tabelas de hierarquização do conhecimento e, de outro lado, mantendo em relação ao mercado de trabalho uma perspectiva centrada no setor público como patrão. 
A rigor não era uma situação que destoava do verificável na maior parte das escolas de Biblioteconomia brasileiras pois, de modo mais intenso ou menos intenso, quase todas estavam submetidas à mesma visão de realidade profissional.

Merece destaque o fato da maioria dos professores em início de carreira ter começado a atuar no ensino nas escolas de Biblioteconomia sediadas em Santa Catarina em condições geralmente insuficientes, fosse pela não experiência anterior de trabalho ou pelo despreparo para a atividade de ensino. Se na primeira situação a prática é necessária para quem vai trabalhar com conteúdos relativos a uma profissão que se notabiliza pelo fazer, na outra a falta de conhecimentos organizados, estudados, ao menos teoricamente, sobre o ensino superior não assegura, a priori, boa qualidade do trabalho realizado. Neste caso específico, vê-se a aliança do não saber fazer com o não saber orientar a como fazer. Mas não era apenas isso, ao não conhecer o que ensinava e nem como deveria ensinar um dado conhecimento, acrescente-se que esses professores, nestas condições, ainda tinham que lidar com o relacionamento humano de sala de aula, com as implicações previsíveis. Tinha-se, de fato, um razoável número de aprendizes de profissionais bibliotecários guindados à condição de professores, sem ao menos terem um base de conhecimento sobre a atividade docente.

Ora, não sendo de fato bibliotecários e nem de fato professores, estes docentes de biblioteconomia aprovados e contratados como tais, também não tinham condições acadêmicas de serem pesquisadores. Não sendo, de fato, integrantes de quaisquer um desses papéis, esses docentes só poderiam ser usuários da literatura então considerada mais segura, originada nos "centros" da Biblioteconomia brasileira, pois se adequariam aos programas de ensino também colados das escolas ali estabelecidas.

Se o contexto internacional estava distante o contexto local também tendia a não interessar a esses docentes na medida em que não havia a necessidade de pesquisá-lo, compreendê-lo, pois com ou sem ele estes professores não corriam riscos de perda de seu emprego e renda.

A discussão de temas importantes, na época, como operação em redes ou consórcios, a gestão compartilhada, etc. também estava em literatura externa, linguisticamente e biblioteconomicamente e, por isso, distante, da mesma forma que a qualificação para o ensino, um tema permanente e visível por sua recorrência mas sempre deixado para frente.

Tudo isso poderia ter sido realizado de outra maneira se houvesse a compreensão do trabalho docente não como um mero conjunto de regras - as técnicas de ensino - mas como o cruzamento de saberes. E daí dá para considerar, usando a formulação de C. Gauthier e outros, que parte dos docentes dos cursos de Biblioteconomia de Santa Catarina, tinham pouca noção ou domínio de saberes disciplinares, saberes experienciais, saberes da tradição e, menos ainda, de saberes da ação pedagógica. E embora não tivessem também saberes curriculares, ao menos tinham essa crença na medida em que os cursos seguiam currículos, programas e planos de ensino.

Não havendo pesquisa, de fato, até pela falta de quadros adequados para liderá-la, mas com tantos mestres e especialistas nestas escolas poder-se-ia esperar encontrar uma grande densidade de atividades de extensão. Contraditoriamente, esta não existiu se tomada sob a perspectiva de criação e prestação de serviços a uma comunidade mais ampla. Assim, pode-se ver uma cidade como Florianópolis, por exemplo, que tem duas escolas de Biblioteconomia, e tantos bairros e distritos, alguns como o Ribeirão da Ilha, distante mais de $30 \mathrm{~km}$ do centro da capital, onde não há serviço descentralizado de biblioteca pública ou iniciativas estimuladas pelos 
cursos de formação bibliotecária que, para além de um carro biblioteca operado pela UDESC, pudesse induzir o poder público ou as comunidades à organização de bibliotecas populares.

Chama atenção a qualquer observador o fato de que, explicitamente, o ensino de Biblioteconomia em Santa Catarina, no período, se olhado parte dos objetivos escritos dos dois cursos, voltar-se-ia ao "ensino centrado no usuário", ao "desenvolvimento no aluno de uma visão crítica da sociedade" e "estímulo à pesquisa biblioteconômica". Na verdade, entre o enunciado e a prática curricular o caminho traçado e a condução realizada são bem distintos. Aqui cito Perrenoud, para confrontar ou levar à reflexão sobre o que fazia a escola de Biblioteconomia em Santa Catarina e seus professores. "Pretende-se, nas formações profissionalizantes, preparar para um ofício que confrontará a prática com situações de trabalho que, a despeito de singularidade de cada um, poderão ser dominadas graças a competências de uma certa generalidade. ... A implementação de uma formação profissionalizante consiste primeiro na correta identificação das situações pertinentes, considerando-se, ao mesmo tempo, as situações relativamente banais, mas que, nem por isso, pedem um tratamento de rotina, e das situações excepcionais, que requerem a totalidade da perícia, da criatividade e do sangue frio do prático. Sem ser simples, esse trabalho é um princípio da transposição didática ${ }^{4}$ na formação profissionalizante” (p. 36). "Identificação das situações pertinentes" para realizar a "transposição didática" supõem de parte dos professores conhecimento do assunto com domínio de campo e conhecimento didático-pedagógico. Supõem também que conhecimento de campo e conhecimento didático-pedagógico permitiriam o cumprimento de um objetivo como “ensino centrado no usuário". Aliado a isso, um conhecimento amplo, com base em tradição acadêmica, vivência social, domínio metodológico, produção científica, poderiam levar ao atendimento de objetivo como "desenvolvimento no aluno de visão crítica da sociedade".

Para responder a esses objetivos explicitados pelas escolas, no período, é evidente que boa parte dos docentes então disponíveis nos Departamentos de Ensino de Biblioteconomia da UFSC e UDESC, especialmente os recém-ingressos nas condições já demonstradas, não estavam suficientemente prontos. Assim, como faziam para "centrar o ensino no usuário" e para "desenvolver no aluno a competência crítica de modo que pudesse ser capaz de transformar a sociedade"?. Uma análise cuidadosa do currículo, suas disciplinas, programas e planos de ensino evidencia que não davam conta disso. Onde estavam os laboratórios ou como se utilizava os meios disponíveis para o centramento do ensino no usuário e na análise de sociedade?

E no caso específico do curso da UFSC, que explicitava como um de seus objetivos formar seu aluno com visão crítica da sociedade, é difícil ver coerência entre este objetivo expresso e o fato de ter extinto em 1991 a exigência do Trabalho de Conclusão de Curso, que se constituia em uma proposta de iniciação à pesquisa estudantil e, portanto, um recurso capaz de atender em parte o objetivo afirmado.

Mais incompreensível é pensar em uma virtual articulação - necessária - entre os chamados conteúdos de Fundamentação Geral e Instrumental e os conteúdos designados como Profissionalizantes, se os Professores dos demais Departamentos que colaboravam com o currículo do Curso e os Professores do então Departamento de Biblioteconomia e Documentação não planejavam juntos os seus planos semestrais de ensino. De que adiantava a existência desses dois blocos de conteúdos sem uma articulação didática. Se os Professores da Fundamentação Geral, a quem caberia fomentar uma formação Humanístico-Social não planejavam juntos com

\footnotetext{
${ }^{4}$ Em PERRENOUD, Philippe, p. 73, "A transposição didática é a sucessão de transformações que fazem passar da cultura vigente em uma sociedade (conhecimentos, práticas, valores, etc.) ao que dela se conserva nos objetivos e programas da escola e, a seguir, ao que dela resta nos conteúdos efetivos do ensino e do trabalho escolar e, finalmente - no melhor dos casos -, ao que se constrói na mente de parte dos alunos."
} 
os Professores da Profissionalização, a quem caberia formar em Técnicas Biblioteconômicas e conhecimentos conexos, os primeiros fundamentavam o que? De outro lado, de que maneira os Professores da Profissionalização ministravam seus conhecimentos de modo a inseri-los na visão de contexto, em tese, ministrada pelos Professores da Fundamentação Geral? Talvez seja mais fácil de ser perguntado do que respondido, no entanto é presumível que o contexto pouco interessava.

De imediato, como não ocorria ou era muito precária essa articulação de conhecimentos via planejamento comum de conteúdos e como o professor de Técnicas Biblioteconômicas não educa no sentido dado por Castells, mas apenas especializa, o que ocorreu foi que as escolas de Biblioteconomia em Santa Catarina promoveram um discurso babélico com uma formação profissional insubsistente, inadequada, insuficiente para atender aos objetivos por elas proclamados. De outro lado, se por sua natureza o conteúdo ou conhecimento especializado logo se defasa, por consequência do avanço tecnológico, a ausência de uma educação, por Fundamentação Geral, articulada a esse conteúdo vai desembocar na titulação de bacharéis pouco mais que alfabetizados e, em geral, incapazes de propor e implementar ações no campo de trabalho sancionado socialmente para o bibliotecário.

Foi isso que as escolas de Biblioteconomia sediadas em Santa Catarina fizeram de 1973 a 1993, ressalvadas as exceções de bacharéis que, num investimento pessoal complementar em formação, ainda durante a graduação, conseguiram se superar. Uma vista rápida no quadro profissional bibliotecário constituído de egressos destas escolas dá uma dimensão da materialidade da fraqueza destes estabelecimentos no período estudado.

Assim, a hipótese anteriormente formulada como resposta à etapa da pesquisa realizada entre 1997 e 1998 se reforça, pois a escola bibliotecária catarinense não estava capacitada e nem a maioria de seus professores preparados para se ocupar de pesquisa e, por isso, não havia como decidirem pelo conhecimento, como um projeto institucional, das questões locais de Santa Catarina referentes à área. Em razão disso, escolas e professores não tinham linhas orientadoras para canalizar a produção de textos. Os professores vocacionados para a geração, debate e publicação de idéias dirigiam-se pelos temários dos eventos em que podiam participar, em geral, fazendo revisões de textos e quase nenhum estudo da sociedade local. A rigor, pesquisas, ou melhor, produção de textos, era uma atividade voluntária e reprodutora da literatura que chegava às mãos daqueles professores. Dessa maneira, as escolas de Biblioteconomia catarinenses não tendo capacidades a serem mobilizadas para a produção local ficaram submetidas ao que seus professores liam na Revista Ciência da Informação (Rio de Janeiro), Revista Brasileira de Biblioteconomia e Documentação (São Paulo), Revista de Biblioteconomia de Brasilia, Anais dos Congressos Brasileiros de Biblioteconomia e Documentação e Anais dos Seminários Nacionais de Bibliotecas Universitárias.

Assim, talvez como busca de uma premissa fundamentadora, retorno a Berger \& Luckman e deles transcrevo uma idéia que a mim parece evidenciar o ocorreu nestes vinte e um anos analisados com as escolas e professores de Biblioteconomia atuantes em Santa Catarina. Toda atividade humana está sujeita ao hábito. Qualquer ação frequentemente repetida torna-se moldada em um padrão, que pode em seguida ser reproduzido com economia de esforço e que ipso facto, é aprendido pelo executante como tal padrão. (p. 77) Para mim, soa razoável que o padrão, conforme verificado no ensino de Biblioteconomia em Santa Catarina, no período estudado, não deveria reproduzir-se nos anos seguintes. No entanto, temo que não seja assim, mesmo porque a escola moldou pessoas que estão aí em um mercado de trabalho, nele inseridas ou não, aproveitadas em seu 
saber ou não e as escolas estão ali, em suas universidades. Os egressos que não ingressaram no mercado de trabalho representam também uma fragilidade das escolas, salvo os casos de quem não tinha um propósito real de atuar em Biblioteconomia. Mas também os que ingressaram no mercado de trabalho podem estar mostrando as fragilidades dessas escolas por não conseguirem magnificar o saber biblioteconômico em todas as suas potencialidades, por reclamarem das condições de trabalho e não conseguirem modificar o entendimento dos tomadores de decisões, por não conseguirem ampliar o número de vagas para a contratação de seus colegas que assim poderiam penetrar no mercado de trabalho bibliotecário, por desistirem de interiorizar a profissão, por não criarem novos serviços para a comunidade, etc.

\section{CONCLUSÃo}

Esta conclusão não poderia ser senão um elenco de perguntas, e um enunciado de preocupações. Até porque, ao longo da análise e interpretação dos dados me perguntei várias vezes se o conhecimento das causas dos pontos fracos identificados na atuação das escolas de Biblioteconomia sediadas em Santa Catarina, de 1973 a 1993, poderia servir para algo além do interesse acadêmico? A partir desta pergunta, conclui que se tornaria irrelevante dizer que esses resultados poderiam orientar a não repetição das mesmas falhas, principalmente porque um dos componentes da realidade que se está tornando regra é a não reposição de quadros docentes nos últimos anos, levando a universidade a contratar professores substitutos sistematicamente. Também dizer que esses resultados dão a dimensão mais palpável da fraqueza da profissão no estado seria uma confissão da incapacidade política da escola e de seus professores no sentido de fomentar a transformação social a partir da postura de liderança de projetos voltados à conquista e ampliação do espaço profissional.

Então, o que talvez me pareça mais importante como resultado do conhecimento destas causas foi poder constatar que a educação bibliotecária em Santa Catarina encobriu com objetivos grandiloquentes a sua incapacidade de ensinar bem, pesquisar e servir a comunidade com uma extensão mobilizadora.

De outro lado, exponho uma outra pergunta, da seguinte maneira: E estas constatações têm que sentido hoje, ano 2000, quando virtualmente ainda se repetem nessas escolas quase todos os mesmos fatores encontrados no período estudado?

Essas são algumas das dúvidas que o estudo proporciona. Em si, tanto vistos sob o plano institucional da profissão quanto da educação profissional, são fortes o bastante para mobilizar as escolas de Biblioteconomia de Santa Catarina, seus docentes, estudantes e egressos no sentido de construir / reconstruir um rumo.

Afinal, esses pontos fracos estão inscritos no caráter da Biblioteconomia catarinense, de todos os seus membros, em todos os seus produtos e serviços. Interferem fortemente na imagem pública da Biblioteconomia no Estado. Pelo sim, pelo não, esses pontos fracos atingem a todos os bibliotecários aqui formados, pelo menos até o ano de 1997, pois mesmo os que se graduaram nesse ano ingressaram no curso ainda em 1993. Contudo, este cronograma é ilusório e as fragilidades detectadas alcançam os formados de hoje e também os que se formarão nos primeiros anos do século XXI, na medida em que esta escola não está isolada de seu meio ambiente social. Ela depende dos campos de estágio onde estão os atuais profissionais, cuja maioria não tem visão de grupo profissional como espaço público e político, não participam - a grande maioria - de associações profissionais, comissões, grupos de trabalho profissionais, eventos técnico-científicos, negligenciando, entre 
outras coisas, a educação continuada. Aliás, são profissionais que, no geral, não sabem, ou pior, não têm o que escrever sobre sua experiência.

\section{BIBLIOGRAFIA}

ABADAL, Ernest; MIRALPEIX, Concepció. La enseñanza de la Biblioteconomia y la Documentación en la universidad española a finales de los noventa. BID - textos universitaris de biblioteconomia i documentació, n. 2, març 1999 [http://www.ub.es/biblio/bid/bid2.htm]

BARRETO, Aldo Albuquerque. A formação de recursos humanos para otimizar a indústria da produção de conhecimento no Brasil. Ciência da Informação, Brasília, v. 19, n. 2, p. 113-116, 1990.

BERGER, Peter; LUCKMANN, Thomas. A construção social da realidade; tratado de sociologia do conhecimento. 6. ed. Petrópolis: Vozes, 1985. 247 p.

BARBOSA, M. L. A sociologia das profissões: em torno da legitimidade de um objeto. BIB Boletim Informativo Bibliográfico das Ciências Sociais, Rio de Janeiro, n. 36, p. 3-30, 1993.

CALENGE, Bertrand. A quoi former les bibliothécaires, et comment? BBF, Paris, v. 40, n. 6, p. 3948, 1995.

CASTELLS, Manuel. A era da informação: economia, sociedade e cultura. São Paulo: Paz e Terra, 1999. $3 \mathrm{v}$.

CATAPAN, Araci H.; THOMÉ, Zeina R. C. Trabalho \& consumo; para além dos parâmetros curriculares. Florianópolis: Insular, 1999.

CUNHA, Regina C. O. da. Tudo o que é sólido se desmancha no ar: a concepção tradicional de currículo também? (Localizado em http://www.ufrgs.br/faced/gtcurric/rcunha.html em 03.02.00)

CURSO de Biblioteconomia [da UDESC]. Site localizado em: http://www.faed.udesc.br/bibliotecon.htm

CURSO de Biblioteconomia da UFSC. Site localizado em: http://www.ced.ufsc.br/bibliote/coord/curso.html

DIAS, Eduardo J. W., PITELLA, Monica C., PONTELLO, A. G. G. Literatura utilizada no ensino de graduação em biblioteconomia no Brasil: produtividade institucional. Perspectivas em Ciência da Informação, Belo Horizonte, v. 1, n.2, p. 157-176, jul./dez. 1996.

ENCONTRO DAS ESCOLAS DE BIBLIOTECONOMIA DA REGIÃO SUL, 3., Florianópolis, 1993. Recomendações. s. n.t. 1 f.

FIGUEIREDO, Nice. - ed. O ensino de Biblioteconomia no Brasil. Brasília: CAPES, 1978. 3 v.

FREIDSON, Eliot. Renascimento do profissionalismo; teoria, profecia e política. São Paulo: Ed. USP, 1998.

GAUTHIER, Clermont e outros. Por uma teoria da pedagogia; pesquisas contemporâneas sobre o saber docente. Ijuí, RS: Ed. UNIJUI, 1998.

GIDDENS, Anthony. As consequências da modernidade. São Paulo: UNESP, 1991. 
GORZ, André. Adeus ao proletariado; para além do socialismo. Rio de Janeiro: Forense-Universitária, 1987.

HARVEY, David. Condição pós-moderna: uma pesquisa sobre as origens da mudança cultural. 4. ed. São Paulo: Loyola, 1994.

HENRIQUES, Márcio S. O pensamento complexo e a construção de um currículo linear. (Localizado em http://www.ufrgs.br/faced/gtcurric/simeone.html em 03.02.00)

IRVING, Ann. Métiers des biblithèques et des services d'information au Royaume-Uni. BBF, Paris, v. 40, n. 6, p. 88-92, 1995.

LIMA, Lauro de Oliveira. Piaget: sugestões aos educadores. Petrópolis: Vozes, 1999.

LOJKINE, Jean. A revolução informacional. São Paulo: Cortez, 1995.

MÜELLER, Suzana P. M., CAMPELLO, Bernadete S.; DIAS, E. J. W. Disseminação e pesquisa em ciência da informação e biblioteconomia no Brasil. Ciência da Informação, Brasília, v. 25, n. 3, p. 337 351, set./dez. 1996.

OHIRA, Maria L. B., MAIA, Maria H. B., SELL, Maria A. Produção científica em biblioteconomia no estado de Santa Catarina. Transinformaçào, Campinas, SP, v. 9, n. 3, p. 68-87, set./dez. 1997.

PERRENOUD, Philippe. Constuir as competências desde a escola. Porto Alegre: Artes Médicas, 1999.

POBLACIÓN, Dinah A., NORONHA, D. P., CURRÁS, Emília. Literatura cinzenta versus literatura branca: transição dos autores das comunicaçòes dos eventos para produtores de artigos. Ciência da Informação, Brasília, v. 25, n. 2, p. 228-242, maio/ago. 1996.

POLKE, Ana Maria A. Biblioteca e educação formal; exposição preliminar para debate. In: CONGRESSO BRASILEIRO DE BIBLIOTECONOMIA E DOCUMENTAÇÃO, 11. João Pessoa, 1982. Anais. João Pessoa: APBPB, 1982. v. 2, p. 75-85.

RAPPORT Mondial sur l'Information - 1997/98. Paris: UNESCO, 1997. p. 117-133 - MORALES CAMPOS, Estela. L'Amérique latine et les Caraibes.

RASCHE, Francisca. Causas da baixa inserção da produção científico-técnica de profissionais da área de Biblioteconomia atuantes em Santa Catarina na literatura utilizada pelas escolas de Biblioteconomia no Estado. Florianópolis, 1999. 1 v. (Relatório de Pesquisa de Iniciação Científica PIBIC/UFSC).

RUMPF, Horst. Los conocimientos no se pueden trasmitir a otros como informaciones. Educación, Tübingen, v. 45, p. 85-97, 1992.

SCHAFF, Adam. A sociedade informática; as consequências sociais da segunda revolução industrial. 3. ed. São Paulo: Brasiliense; UNESP, 1992.

SCHWARTZMAN, Simon. A força do novo: por uma sociologia dos conhecimentos modernos no Brasil. Revista Brasileira de Ciências Sociais, v. 2, n. 5, p. 47-66, 1987.

SEMINÁRIO DE OTIMIZAÇÃO DO ENSINO DE BIBLIOTECONOMIA, Recife, PE, 1992. Documento-síntese das conclusões finaais ... Recife, ABEBD, 1982. 10 p. 
SOUZA, Francisco das Chagas de. A educação de profissionais de informação documentária em Santa Catarina. Florianópolis: UFSC: BDC: FUNPESQUISA, 1998. 40 p. +

SOUZA, Francisco das Chagas de. Educação superior, sociedade e formação de bibliotecários. In: Seminário Biblioteca, educação e sociedade no terceiro milênio. Ijuí, RS, ago 1999. Disponível em http://www.ced.ufsc.br/bibliote/dep/nipeeb.html

. Curso de Biblioteconomia; 26. ano - 1973-1999. Florianópolis: 1999. 15 f. +

. Organização do conhecimento na sociedade. Florianópolis: UFSC-CED - Núcleo de Publicações, 1998. 107 p.

Biblioteconomia no Brasil: profissão e educação. Florianópolis: ACB; UFSC-BU, 1997. 141 p.

A educação bibliotecária brasileira: comparação com a educação bibliotecária em alguns países europeus e asiáticos e uma proposta para atender a modernidade no Brasil. Florianópolis: UFSC; BDC, 1997. 105 f. (Relatório de Pesquisa)

Modernização e biblioteconomia nova no Brasil. Piracicaba: 1994. 405 p. Tese (Doutorado em Educação. Universidade Metodista de Piracicaba).

Biblioteconomia, educação e sociedade. Florianópolis: Ed. UFSC, 1993. 102 p.

Ensino de biblioteconomia no Brasil: o modelo norte-americano. Informação \& Sociedade, v. 3,

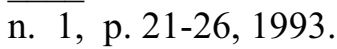

A construção escolar do bibliotecário brasileiro: ontem, hoje e amanhã. Ciência da Informação, v. 20, n. 2, p. 181-190, jul./dez. 1991.

O ensino de biblioteconomia no contexto brasileiro. Florianópolis: Ed. UFSC, 1990.

A biblioteconomia em Santa Catarina; primeira abordagem. Cadernos do CED, v. 4, n. 9/10, p. $\overline{10-28}$, jul./dez. 1987.

STENBERG, Catharina; HÖGLUND, Lars. Bibliothéconomie et sciences de l'information en Suède. BBF, Paris, n 2, 1998, p. 55-60.

TÁlAMO, Maria de Fátima G. M. Cursos de graduação profissionalizantes: formação e mercado de trabalho. Revista Brasileira de Biblioteconomia e Documentação, São Paulo, v. 26, n. 1/ 2, p. 64-71, 1993.

TESSER, Ozir. O currículo e a produção do conhecimento: vinculação entre educação, trabalho e cidadania na perspectiva das classes populares. Educação em debate, Fortaleza, v. 14, n. 2, p. 27-40, jul./dez. 1987.

TORRES SANTOMÉ, Jurjo. Currículos flexíveis. (Localizado em http://www.a-pagina-daeducacao.pt/arquivo/artigos/u728.html em 03.02.00)

VARGAS, Lilia M. Adequação dos cursos de Biblioteconomia ao mercado de trabalho. In: JORNADA SUL-RIO GRANDENSE DE BIBLIOTECONOMIA E DOCUMENTAÇÃO, 7, Porto Alegre, 1982. Anais. Porto Alegre: ARB, 1982. p. 72-81.

VEIGA, Evangelina de A. Ensino e biblioteconomia. . In: JORNADA SUL-RIO GRANDENSE DE BIBLIOTECONOMIA E DOCUMENTAÇÃO, 7, Porto Alegre, 1982. Anais. Porto Alegre: ARB, 1982. p. 64-71. 
VISÃO e ação: a universidade do século XXI. Rio de Janeiro: EdUERJ, 1999.

WEECH, Terry L. L'évolution des métiers des bibliothèques aus Etats-Unis. BBF, Paris, v. 40, n. 6, p. 82-88, 1995.

WEBER, Max. A ética protestante e o espírito do capitalismo. São Paulo: Pioneira, 1999.

WURMAN, R. S. Ansiedade de informação. São Paulo: Cultura, 1991. 377 p. 